\title{
Biochemical Responses in Mice Experimentally Infected with Paracoccidioides brasiliensis and Treated with Canova
}

\author{
Gisele Takahachi $^{1}$, Márcia Luzia Ferrarezi Maluf ${ }^{1}$, Terezinha Inez Estivalet Svidzinski ${ }^{1}$, \\ Luciene Setsuko Akimoto-Günther ${ }^{1}$, Márcia Rosangela Neves de Oliveira Hübler ${ }^{1}$, Ciomar \\ Aparecida Bersani-Amado ${ }^{2}$ and Roberto Kenji Nakamura Cuman ${ }^{2 *}$ \\ ${ }^{1}$ Departamento de Análises Clínicas; ${ }^{2}$ Departamento de Farmácia e Farmacologia; Universidade Estadual de \\ Maringá; Av. Colombo, 5790; rkncuman@uem.br; 87020-900; Maringá - PR - Brasil
}

\begin{abstract}
The objective of this work was to evaluate biochemical parameters in Paracoccidioides brasiliensis infected mice and the effect of Canova medicine on these parameters. Mice infected with the isolate Paracoccidioides brasiliensis Pb18 and treated with Canova for 17 weeks were used. The biochemical parameters analysed were the levels of aspartate aminotransferase, alanine aminotransferase, alkaline phosphatase and amylase, and the concentration of total proteins, albumin and globulins. The results suggested that the animals that were treated with Canova had less functional alterations in their internal organs.
\end{abstract}

Key words: Paracoccidioidomycosis, biochemical profile, Canova, Paracoccidioides brasiliensis

\section{INTRODUCTION}

The Canova ${ }^{\circledR}$ (Canova of Brazil) is a natural compound commercialised in Brazil and Argentina. This highly diluted and succussed medicine is made of Aconitum napellus, Arsenicum album, Bryonia alba, Lachesis muta and Thuya occidentalis, all components listed in the Brazilian Homeopathic Pharmacopoeia. This medicine has been used for patients with cancer and other diseases, such as AIDS, where the immunological response is reduced. Clinical and experimental studies suggest that Canova treatment promotes improvement in infectious and inflammatory conditions, as well as the reduction and, in some cases, the regression of the tumour (Sasaki et al., 2001; Buchi and Del Vecchio, 2002; Sato et al., 2004). Some recent experimental studies have shown that the mechanism of action of the compound is probably due to the increase in the immune response through macrophage activation (Piemonte and Buchi, 2002). In vitro studies, Canova promoted the decrease of the production of $\alpha$-Tumour Necrosis Factor (TNF- $\alpha$ ) (Piemonte and Buchi, 2002), stimulation of leishmanicidal activity, and the production of nitric oxide in elicited macrophages (Pereira et al., 2005), suggesting that this medicine might act on some immune response mediators.

Paracoccidioidomycosis (PCM) is a granulamatous systemic disease, caused by the fungus Paracoccidioides brasiliensis, and it is geographically limited to Latin American countries (Restrepo, 1985). It most frequently attacks males between 30 to 59 years old, from rural areas. A severe disease with progressive evolution, PCM affects mainly the lungs,

\footnotetext{
Author for correspondence
} 
ganglions and mucosa, as well as other organs and systems, manifesting a range of clinical signs and symptoms (Wanke and Londero, 1994).

In the therapeutic management of PCM, antifungal drugs, procedures that improve the general conditions of the patient and post-therapeutic monitoring are used. Beyond this, the patient with PCM requires general procedures that improve the state of protein and caloric malnutrition and the cellular immunodepression generally related to $P$. brasiliensis infection (Del Negro, 1986). In PCM, the effective protector response of the host depends primarily on the immunity mediated by cells, where the neutrophils and macrophages perform important actions through the phagocytosis of the infectious agent (Cano et al., 1992; Popi et al., 2002). The polyclonal activation of $\mathrm{B}$ cells and the production of high levels of specific antibodies are indications of the progressive disease (Calich et al., 1998).

PCM may be experimentally reproduced by the intraperitoneal inoculation of yeast cells of $P$. brasiliensis in mice (Singer-Vermes et al., 1993). To monitor the evolution of the disease, it is possible to use biochemical parameters, since the intraperitoneal inoculation of mice causes intense peritonitis in the animals, with a stronger effect in the liver, pancreas and spleen (Xidieh et al., 1994). The objective of this study was to evaluate biochemical parameters in Paracoccidioides brasiliensis infected mice and the effect of Canova medicine on these parameters.

\section{MATERIALS AND METHODS}

\section{Fungus}

The isolate Paracoccidioides brasiliensis $\mathrm{Pb} 18$ from the Mycology Collection of the Pathology Department in the Medical Faculty of the State University of São Paulo (UNESP - Botucatu Campus) was used. The yeast cells were cultured in YPD (Yeast extract, Casein-peptone, D-glucose, agar and bi-distilled water) semi-solid medium at $35^{\circ} \mathrm{C}$ for seven days. To prepare the inoculum, the cells were washed three times with sterile phosphate buffer solution (PBS) $\mathrm{pH}$ 7.2. The cellular viability was determined using the Janus Green vital stain (Berliner and Reca, 1966). Cultures with a minimum of $80 \%$ viability were used and the concentration adjusted by counting in a Neubauer chamber.

\section{Animals}

Four to six weeks-old male mice of Swiss strain from the Central Animal Facilities of the State University of Maringá were used. The animals were divided in four groups: Canova (50 animals infected and treated with Canova); Itraconazole (40 animals infected and treated with Itraconazole); Positive Control (50 animals infected but not treated) and Negative Control (50 animals not infected and not treated). The mice were infected with $0.5 \mathrm{~mL}$ of a fungus suspension with a concentration of $1.0 \times 10^{7}$ cells $\mathrm{mL}^{-1}\left(5 \times 10^{6}\right.$ yeast cells) by intraperitoneal route. During the period of the experiments, the animals were kept in the Animal Facilities of the Laboratory of Inflammation in the Department of Pharmacy and Pharmacology of the State University of Maringá, where they received water ad libitum and balanced food. The use of the animals in the experiments followed the Brazilian Animal Experimentation Ethics Code (COBEA).

\section{Treatment}

The animals were treated with Canova ${ }^{\circledR}$ medicine (Canova of Brazil) $\left(0.2 \mathrm{~mL}\right.$ day $^{-1}$, intra-gastric route) (Pereira et al., 2005) or Itraconazole as reference drug, (Sporanox ${ }^{\circledR}$, Jansen) $\left(20 \mathrm{mg} \mathrm{Kg}^{-1}\right.$ day $^{-1}$, intra-gastric route) (McEwen et al., 1985). The treatment with Canova was started on the same day that the infection was induced, while the treatment with Itraconazole only started 4 weeks after infection induction. The treatments were continued until the $17^{\text {th }}$ week after infection induction.

\section{Treatment Evaluation}

In weeks 4, 6, 10, 14 and 17 after infection, 10 mice from each group were anaesthetised and blood samples were collected to determine the levels of activity of: alanine aminotransferase (ALT), aspartate aminotransferase (AST), alkaline phosphatase (ALP) and amylase, using commercial kits (Diasys Diagnostic Systems GmbH and Co. KG.). U.V. kinetic tests were used for AST and ALT, while photometric kinetic tests were used for ALP, methodologies developed according to the International Federation of Clinical Chemistry and Laboratory Medicine (IFCC). The levels of activity of amylase were determined using photometric enzymatic tests with 4,6-ethylidene-(G7)-p-nitrophenyl-(G1)- $\alpha$ D-maltoheptaoside (EPS-G7) as substrate. Total 
proteins were assayed according to the biuret method, and albumin, using green bromocresol (Labtest Diagnóstica S.A.), were also quantified. The globulin concentration was determined by the difference between total proteins and albumin. All the quantifications were performed in Vitalab Selectra $2^{\circledR}$ analyser system and the incubations were carried out at $37^{\circ} \mathrm{C}$.

\section{Statistical Analysis}

The Software GraphPad Prism ${ }^{\circledR}$ (Graphpad Software, Inc.) was used for statistical analysis. The results were expressed as mean \pm standard error of the mean (SEM). The different groups in each week were analysed using variance analysis (ANOVA) for multiple comparisons, followed by the Tukey test. The significance level used was 0.05 .

\section{RESULTS}

\section{Alkaline Phosphatase (ALP)}

In the $4^{\text {th }}$ week of infection, the ALP activity levels in the animals from the positive control group were higher compared to those from the negative control group $(\mathrm{p}<0.05)$. In this week and in the $10^{\text {th }}$ week of infection, the animals from the Canova group presented lower levels of ALP activity $(\mathrm{p}<0.05)$ compared to the positive control group, while the Itraconazole group had lower ALP activity levels $(\mathrm{p}<0.05)$ in the $6^{\text {th }}, 10^{\text {th }}$ and $14^{\text {th }}$ weeks of infection (Table 1$)$.

\section{Alanine Aminotransferase (ALT)}

The ALT activity levels were higher $(\mathrm{p}<0.05)$ in the animals from the positive control group when compared to the negative control group in the $4^{\text {th }}$ week of infection. The Canova group displayed lower ALT activity levels $(p<0.05)$ in the $4^{\text {th }}, 10^{\text {th }}$ and $14^{\text {th }}$ weeks of infection compared to the positive control group, and also showed no statistical difference when compared to the negative control group in the $10^{\text {th }}$ and $14^{\text {th }}$ weeks of infection. For the Itraconazole group, no significant differences were observed when compared to the control groups in the period studied (Table 1).

\section{Aspartate Aminotransferase (AST)}

The AST activity levels in the positive control group were higher $(\mathrm{p}<0.05)$ compared to the negative control group in the $4^{\text {th }}, 10^{\text {th }}, 14^{\text {th }}$ and $17^{\text {th }}$ weeks of infection. The animals of the Canova group presented lower activity levels $(p<0.05)$ compared to the positive control group only in the $6^{\text {th }}$ and $14^{\text {th }}$ weeks of infection. However, in all the weeks studied, no significant difference between the AST activity levels of the Canova group and the negative control group was observed. In the Itraconazole group, lower activity levels were observed in the $10^{\text {th }}$ and $14^{\text {th }}$ weeks of infection when compared to the positive control group (Table 1).

Table 1 - Effect of the Canova medicine on serum levels of hepatic enzymes activities in mice of Swiss strain infected with P. brasiliensis.

\begin{tabular}{|c|c|c|c|c|c|c|c|c|c|c|c|c|}
\hline \multirow[t]{2}{*}{ WI } & \multicolumn{4}{|c|}{ Alkaline Phosphatase $\left(\mathbf{U} \mathbf{L}^{-1}\right)$} & \multicolumn{4}{|c|}{ Alanine Aminotransferase $\left(\mathrm{U} \mathrm{L}^{-1}\right)$} & \multicolumn{4}{|c|}{ Aspartate Aminotransferase $\left(\mathrm{U}^{-1}\right)$} \\
\hline & C neg & Cpos & Canova & Itra & C neg & C pos & Canova & Itra & C neg & C pos & Canova & Itra \\
\hline 4 & $71 \pm 2.5$ & $117 \pm 2.3^{\#}$ & $88 \pm 7.5 * \#$ & --- & $4 \pm 0.7$ & $27 \pm 2.2^{\#}$ & $17 \pm 2.2 * \#$ & --- & $36 \pm 5.0$ & $71 \pm 10.4^{\#}$ & $46 \pm 4.3$ & ---- \\
\hline 6 & $72 \pm 5.7$ & $83 \pm 4.8$ & $78 \pm 11.7$ & $39 \pm 5.3 *^{\#}$ & $5 \pm 0.8$ & $9 \pm 2.5$ & $5 \pm 0.9$ & $4 \pm 0.7$ & $40 \pm 2.9$ & $84 \pm 19.5$ & $34 \pm 5.1 *$ & $49 \pm 6.4$ \\
\hline 10 & $79 \pm 3.4$ & $94 \pm 7.6$ & $29 \pm 6.2 * \#$ & $34 \pm 4.8 *^{\#}$ & $7 \pm 1.3$ & $10 \pm 2.5$ & $4 \pm 0.6^{*}$ & $4 \pm 0.9$ & $48 \pm 8.4$ & $100 \pm 18.9^{\#}$ & $60 \pm 14.3$ & $40 \pm 5.2^{*}$ \\
\hline 14 & $71 \pm 2.8$ & $77 \pm 6.3$ & $64 \pm 4.0^{*}$ & $48 \pm 5.5^{* \#}$ & $7 \pm 0.9$ & $8 \pm 1.8$ & $3 \pm 0.5^{*}$ & $5 \pm 0.6$ & $51 \pm 6.5$ & $148 \pm 20.9^{\#}$ & $94 \pm 13.7 *$ & $69 \pm 7.8^{*}$ \\
\hline 17 & $71 \pm 2.8$ & $74 \pm 2.0$ & $59 \pm 5.9$ & $69 \pm 10.2$ & $9 \pm 1.0$ & $10 \pm 4.5$ & $6 \pm 1.0$ & $4 \pm 0.8$ & $58 \pm 10.4$ & $107 \pm 18.1^{\#}$ & $85 \pm 6.9$ & $74 \pm 6.4$ \\
\hline
\end{tabular}

The results represent the mean \pm SEM of the negative control group (Cneg), positive control group (Cpos), and the groups treated with Canova $-0.2 \mathrm{~mL} \mathrm{day}^{-1}$ intra-gastric route (Canova) and Itraconazole - $20 \mathrm{mg} \mathrm{kg}^{-1}$ day $^{-1}$ intra-gastric route (Itra), in the weeks $4,6,10,14$ and 17 after infection, all with $n=10$. WI = weeks of infection.

$\left({ }^{*} \mathrm{p}<0.05\right.$ compared to the positive control group - Anova).

( ${ }^{\#}$ < 0.05 compared to the negative control group - Anova).

\section{Amylase}

In the $10^{\text {th }}$ week of infection, an increase in the amylase serum activity levels was observed in the positive control group, compared to the negative control group $(\mathrm{p}<0.05)$. This increase was not observed in the Canova and Itraconazole groups, where the values were lower $(\mathrm{p}<0.05)$ than those of the positive control group, and remained similar to the activity levels found in the animals of the negative control group. In the $14^{\text {th }}$ week of infection there was also an increase in the amylase levels $(\mathrm{p}<0.05)$ of the positive control group when 
compared to the negative group, while the Canova and Itraconazole groups were not statistically different from either of the control groups (Fig.1).

\section{Total Proteins}

An increase in the concentrations of total proteins $(\mathrm{p}<0.05)$ in the positive control group in the $4^{\text {th }}$, $6^{\text {th }}, 10^{\text {th }}$ and $17^{\text {th }}$ weeks of infection was observed when compared with the negative control group. A significant decrease in the concentration of total proteins in the Canova and Itraconazole groups, compared to the positive control group, was observed in the $10^{\text {th }}$ week of infection (Table 2).

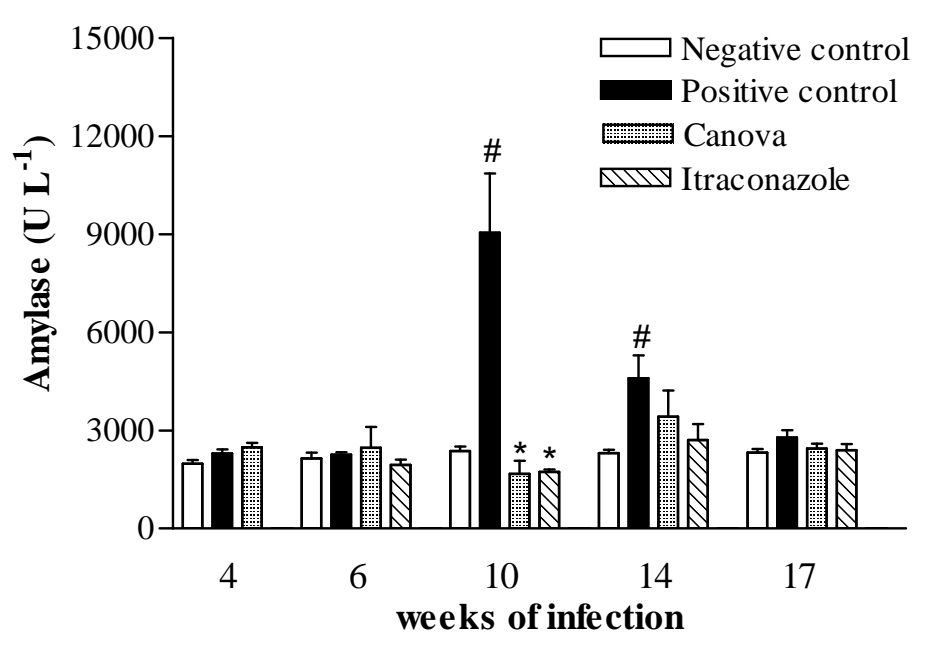

Figure 1 - Effect of the Canova medicine on serum amylase in mice of Swiss strain infected with $P$. brasiliensis.

The results represent the mean \pm SEM of the negative control group, positive control group, and the groups treated with Canova $\left(0.2 \mathrm{~mL}\right.$ day $^{-1}$ intra-gastric route $)$ and Itraconazole $\left(20 \mathrm{mg} \mathrm{kg}^{-1} \mathrm{day}^{-1}\right.$ intra-gastric route), in weeks 4, 6, 14 and 17 after infection; $n=10$. (* $\mathrm{p}<0.05$ compared to the positive control group - Anova). $(\# p<0.05$ compared to the negative control group - Anova).

\begin{abstract}
Albumin
Lower concentrations of albumin were detected in the $10^{\text {th }}$ week of infection in the positive control group. The Canova group presented a significant decrease in the concentrations of albumin serum, compared to the positive control group, only four weeks after infection induction. Significant differences were observed when the negative control group and Canova group were compared in the $10^{\text {th }}$ week of infection, remaining similar in the following weeks studied. For the Itraconazole group, no significant differences were found in any of the weeks studied, when compared to the positive control group, but when compared to the negative control group, significant differences were observed in the $6^{\text {th }}$ and $10^{\text {th }}$ weeks of infection (Table 2).
\end{abstract}

\section{Globulins}

High levels of globulins in the positive control group were observed in the $4^{\text {th }}, 6^{\text {th }}$ and $10^{\text {th }}$ weeks of infection compared to the negative control group $(\mathrm{p}<0.05)$. The Canova and Itraconazole groups displayed lower concentrations $(\mathrm{p}<0.05)$, than the positive and negative control groups in the $10^{\text {th }}$ week of infection. When compared with the negative control, a significant increase of globulins was observed in the Canova group in the $4^{\text {th }}, 14^{\text {th }}$ and $17^{\text {th }}$ weeks after infection, while in the Itraconazole group, this was observed only in the $17^{\text {th }}$ week of infection (Table 2). 
Table 2 - Effect of the Canova medicine on serum concentrations of total proteins, albumin and globulins, in mice of Swiss strain infected with $P$. brasiliensis.

\begin{tabular}{|c|c|c|c|c|c|c|c|c|c|c|c|c|}
\hline \multirow{2}{*}{ WI } & \multicolumn{4}{|c|}{ Total Proteins $\left(\mathrm{g} \mathrm{dL}^{-1}\right)$} & \multicolumn{4}{|c|}{ Albumin (g dL $\left.\mathrm{dL}^{-1}\right)$} & \multicolumn{4}{|c|}{ Globulins ( $\left(\mathbf{d L}^{-1}\right)$} \\
\hline & C neg & C pos & Canova & Itra & C neg & C pos & Canova & Itra & C neg & C pos & Canova & Itra \\
\hline 4 & $4.6 \pm 0.12$ & $5.8 \pm 0.08^{\#}$ & $5.6 \pm 0.12^{\#}$ & --- & $2.1 \pm 0.10$ & $2.4 \pm 0.05$ & $2.1 \pm 0.08 *$ & --- & $2.4 \pm 0.09$ & $3.4 \pm 0.07^{\#}$ & $3.6 \pm 0.10^{\#}$ & ---- \\
\hline 6 & $5.0 \pm 0.12$ & $5.5 \pm 0.08^{\#}$ & $5.0 \pm 0.07$ & $5.0 \pm 0.28$ & $2.1 \pm 0.02$ & $2.0 \pm 0.06$ & $1.8 \pm 0.07$ & $1.7 \pm 0.18^{\#}$ & $2.9 \pm 0.13$ & $3.5 \pm 0.02^{\#}$ & $3.2 \pm 0.10$ & $3.3 \pm 0.26$ \\
\hline 10 & $5.8 \pm 0.06$ & $6.3 \pm 0.07^{\#}$ & $3.3 \pm 0.09^{\#} *$ & $4.7 \pm 0.15^{\#} *$ & $2.0 \pm 0.14$ & $1.5 \pm 0.16^{\#}$ & $1.1 \pm 0.11^{\#}$ & $1.5 \pm 0.06^{\#}$ & $3.8 \pm 0.07$ & $4.9 \pm 0.13^{\#}$ & $2.2 \pm 0.08^{\# *}$ & $3.2 \pm 0.12^{\# *}$ \\
\hline 14 & $5.3 \pm 0.14$ & $5.5 \pm 0.04$ & $5.9 \pm 0.11^{\#}$ & $5.1 \pm 0.23$ & $2.1 \pm 0.15$ & $2.0 \pm 0.04$ & $2.2 \pm 0.12$ & $1.8 \pm 0.11$ & $3.2 \pm 0.12$ & $3.5 \pm 0.07$ & $3.7 \pm 0.14^{\#}$ & $3.3 \pm 0.16$ \\
\hline 17 & $4.9 \pm 0.14$ & $5.5 \pm 0.08^{\#}$ & $5.7 \pm 0.12^{\#}$ & $5.6 \pm 0.19^{\#}$ & $1.8 \pm 0.08$ & $2.0 \pm 0.09$ & $1.9 \pm 0.15$ & $1.9 \pm 0.12$ & $3.1 \pm 0.12$ & $3.5 \pm 0.16$ & $3.7 \pm 0.10^{\#}$ & $3.7 \pm 0.10^{\#}$ \\
\hline
\end{tabular}

The results represent the mean \pm SEM of the negative control group (Cneg), positive control group (Cpos), and the groups treated with Canova $-0.2 \mathrm{~mL} \mathrm{day}^{-1}$ intra-gastric route (Canova) and Itraconazole $-20 \mathrm{mg} \mathrm{kg}^{-1}$ day $^{-1}$ intra-gastric route (Itra), in the weeks 4, 6, 10, 14 and 17 after infection, all with $n=10$. WI $=$ weeks of infection.

$\left({ }^{*} \mathrm{p}<0.05\right.$ compared to the positive control group - Anova).

$\left({ }^{\#} \mathrm{p}<0.05\right.$ compared to the negative control group - Anova).

Table 3 - Effect of the Canova medicine on albumin/globulins rate in mice of Swiss strain infected with $P$. brasiliensis.

\begin{tabular}{ccccc}
\hline WI & \multicolumn{3}{c}{ Albumin / Globulins } \\
\cline { 2 - 4 } & C neg & C pos & Canova & Itra \\
\hline 4 & 0.874 & $0.699^{\#}$ & $0.591^{\#}$ & ---- \\
6 & 0.729 & $0.575^{\#}$ & $0.557^{\#}$ & $0.539^{\#}$ \\
10 & 0.529 & $0.301^{\#}$ & $0.508^{*}$ & $0.480^{*}$ \\
14 & 0.685 & 0.575 & 0.607 & 0.535 \\
17 & 0.573 & 0.597 & 0.526 & 0.512 \\
\hline
\end{tabular}

The results represent albumin/globulins rate of the negative control group (Cneg), positive control group (Cpos), and the group treated with Canova . WI = weeks of infection.

$\left({ }^{*} \mathrm{p}<0.05\right.$ compared to the positive control group - Anova).

$\left({ }^{\#} \mathrm{p}<0.05\right.$ compared to the negative control group - Anova)

\section{DISCUSSION}

Innumerable disturbances, including inflammation, necrosis and biliary obstruction result in the release of cellular enzymes into blood circulation. The intraperitoneal inoculation of $P$. brasiliensis causes intense peritonitis in animals, with a stronger effect in the pancreas, spleen and liver (Singer-Vermes et al., 1993; Xidieh et al., 1994). Therefore, the determination of the AST, ALT, ALP and amylase activities, as well as the measurements of total proteins, albumin and globulins, may be used as sensitive markers for monitoring the evolution of the infection and the treatment of the animals. The cytoplasmic enzyme ALT is more specific to the liver, but it may also be found in other organs like the heart and skeletal muscle. While AST is present in the mitochondria and in the cytoplasm of hepatic cells, skeletal muscle, heart, kidneys and erythrocytes (Moss and Henderson, 1998).

The levels of AST and ALT always increase when the disease affects the integrity of the hepatic cells. High levels of ALT activity in the serum are rarely observed in conditions other than that of hepatic parenchymatous disease, therefore, the values of the transaminases are useful for monitoring the evolution of acute or chronic parenchymal hepatopathy (Weisiger, 1993). ALP is present in the liver, bones, intestinal mucosa, placenta and kidneys. The determination of ALP in the serum is of particular interest in the investigation of hepatobiliar disease. The response of the liver to any form of biliary obstruction is to synthesise 
more ALP in other words, enzymatic induction. The main synthesis sites are the hepatocytes adjacent to biliary canalicules (Moss and Henderson, 1998).

The results related to the activity of AST, ALT and ALP obtained from the positive control group animals (infected but not treated), showed the chronic character of the infection, with a significant increase of ALT and ALP activity in the $4^{\text {th }}$ week of infection, and a progressive increase of AST after this week. The data obtained are in agreement with the literature that indicates a discrete increase in the AST and ALP activity levels in patients with PCM (Fiorilo and Martinez, 1982). In relation to the group treated with Canova, lower levels of activity for these hepatic enzymes were observed, even in the weeks when the positive control group animals had the highest levels. In the group treated with Canova, the activities of these enzymes were very similar to those of the group treated with Itraconazole (the reference drug), and to those of the negative control group (without infection), suggesting that the animals treated with the Canova medicine had fewer hepatic injuries than the positive control group animals.

Amylase is synthesised by pancreatic acinar cells and secreted thereafter into the intestine by a system of pancreatic channels. In pancreatitis transitory elevation of amylase serum activity occurs (Moss and Henderson, 1998). The results for the positive control group animals indicated a significant increase in amylase activity levels in the $10^{\text {th }}$ and $14^{\text {th }}$ weeks of infection, when the infection should be more severe since amylase serum levels are an efficient parameter for evaluating the severity in murine experimental PCM (Xidieh, et al., 1994). On the other hand, when the group treated with Canova was evaluated, it was observed that the levels of amylase activity were very close to those of the negative control group and the group treated with Itraconazole, suggesting that in the treated animals, the pancreas was less affected.

Increased total proteins was observed in positive control group animals. In the $10^{\text {th }}$ week after infection, the positive control group animals albumin values were significantly lower than negative control group animals values (Table 2). However in this week a high concentration of globulin was found, as happened in severe cases of the disease (Martinez, 1994). In PCM, the proportion of albumin was decreased due to its decreased synthesis by the liver, and was related to the extent of the severity of the damage in the internal organs, such as liver, lungs and intestine (Fiorilo and Martinez, 1982). When the Canova treated group was analysed, it was observed that the proportions of albumin and globulins were maintained in all the weeks studied, as was also observed with the Itraconazole group (Table 2, 3). The biochemical profile obtained from $P$. brasiliensis infected but non treated mice, suggested functional alterations in liver and pancreas, which were more severe than in Itraconazole and Canova treated animals. New studies should be made about Canova medicine, mainly with the aim of elucidating its mechanism of action.

\section{ACKNOWLEDGEMENTS}

This work was supported partially by Conselho Nacional de Desenvolvimento Científico e Tecnológico and Laboratório de Ensino e Pesquisa em Análises Clínicas da Universidade Estadual de Maringá. We thank Dr. Roberto Piraíno by kindly providing the samples of the Canova medication. We also thank Jailson Araújo Dantas and Celia Regina Miranda for technical assistance.

\section{RESUMO}

A Paracoccidioidomicose é uma micose sistêmica endêmica em alguns países da América Latina. Essa doença afeta principalmente pulmões, gânglios e mucosas, além de causar diminuição da imunidade celular. $\mathrm{O}$ medicamento Canova tem sido utilizado com sucesso por pacientes imunodeprimidos, como por exemplo portadores de câncer e de AIDS. O objetivo desse trabalho foi avaliar aspectos bioquímicos em camundongos infectados com Paracoccidioides brasiliensis e os efeitos do medicamento Canova sobre esses parâmetros. Foram utilizados camundongos infectados com o isolado de Paracoccidioides brasiliensis $\mathrm{Pb} 18$ e tratados com o medicamento Canova durante dezessete semanas. Os parâmetros bioquímicos analisados foram níveis de atividade de aspartato amino transferase, alanina amino transferase, fosfatase alcalina e amilase, concentração de proteínas totais, albumina e globulinas. Os resultados obtidos sugerem que os 
animais que receberam tratamento com o medicamento Canova tiveram menores alterações funcionais nos seus órgãos internos.

\section{REFERENCES}

Berliner, M. D. and Reca, M. E. (1966), Vital staining of Histoplasma capsulatum with Janus Green B. Saboraudia, 5, 26-29.

Buchi, D. F. and Del Vecchio, M. (2002), Qualidade de vida para pacientes com câncer e Aids. Mita'y, 1, 33-38.

Calich, V. L. G.; Vaz, C. A. C. and Burger, E. (1998), Immunity to Paracoccidioides brasiliensis infection. Res. Immunol., 149, 407-417.

Cano, L. E.; Arango, R.; Salazar, M. E.; Brummer, E.; Stevens D. A. and Restrepo A. (1992), Killing of Paracoccidioides brasiliensis conidia by pulmonary macrophages and the effects of cytokines. J. Med. Vet. Mycol., 30, 161-168.

Del Negro, G. (1986), Tratamento: noções práticas. InParacoccidioidomicose. J. Pneumol., 12, 41-60.

Fiorilo, A. M. and Martinez, R. (1982), Exames Complementares. In: Paracoccidioidomicose. São Paulo: Savier-EDUSP. pp. 179-191.

Martinez, R. (1994), Other Laboratory Tests: Hematologic and Biochemical Changes. In: Paracoccidioidomycosis. Boca Raton: CRC Press. pp. 365-369.

McEwen, J. G.; Peters, G. R. and Blashke, T. F. (1985), Treatment of paracoccidioidomycosis with itraconazole in a murine model. J. Trop. Med. Hyg., 88, 295-299.

Moss, D. W. and Henderson, A. R. (1998), Enzimas. In: Burtis, C. A. and Ashwood, E. R. Tietz Fundamentos de Química Clínica. Rio de Janeiro: Guanabara Koogan. pp. 275-325.

Pereira, W. K. V.; Lonardoni, M. V. C.; Grespan, R.; Caparroz-Assef, S. M.; Cuman, R. K. N. and BersaniAmado, C. A. (2005), Immunomodulatory effect of Canova medication on experimental Leishmania amazonensis infection. J. Infect, 51, 157-164.

Piemonte, M. R. and Buchi, D. F. (2002), Analysis of IL-2, IFN- $\gamma$ and TNF- $\alpha$ production, $\alpha_{5} \beta_{1}$ integrins and actin filaments distribution in peritoneal mouse macrophages treated with homeopathic medicament. J. Submicrosc. Cytol. Pathol., 34, 225-263.

Popi, A. F.; Lopes, J. D. and Mariano, M. (2002), GP 43 from Paracoccidioides brasiliensis inhibits macrophage functions. An evasion mechanism of the fungus. Cell Immunol., 218, 87-94.

Restrepo, A. M. (1985), The ecology of Paracoccidioides brasiliensis: a puzzle still unsolved. J. Méd. Vet. Mycol., 23, 323-334.
Sasaki, M. G. M.; Mariano, F. C.; Gurgel, L. P. and Probst, S. (2001), Estudo clínico randomizado placebo controlado para avaliar a eficácia e segurança do Método Canova ${ }^{\circledR}$ na terapêutica de pacientes portadores de HIV/Aids em uso de anti-retrovirais. Braz J Infect Dis, 5, 58.

Sato, D. Y. O.; Wal, R.; Oliveira, C. C.; Cattaneo, R. I. I.; Malvezzi, M.; Garbado, J. and Buchi, D. F. (2004), Histopathological and immunophenotyping studies on normal and sarcoma 180-bearing mice treated with a complex homeopathic medication. Homeopathy, 94, 26-32.

Singer-Vermes, L. M.; Caldeira, C. B.; Burger, E. and Calich, V. L. G. (1993), Experimental murine paracoccidioidomycosis: relationship among the dissemination of the infection, humoral and cellular immune responses. Clin Exp Immunol, 94, 75-79.

Wanke, B. and Londero, T. A. (1994), Epidemiology and Paracoccidioidomycosis Infection. In: Paracoccidioidomycosis. Boca Raton: CRC Press. pp. 109-120.

Weisiger, R. A. (1993), Exames de laboratório na doença hepática. In: Tratado de Medicina Interna. Rio de Janeiro: Guanabara Koogan. pp. 776-780.

Xidieh, C. F.; Singer-Vermes, L. M.; Calich, V. L. G. and Burger, E. (1994), Plasma amylase levels as a marker of disease severity in an isogenic murine model of paracoccidioidomycosis. J. Med. Vet. Mycol., 32, 37-45.
Received: March 01, 2005; Revised: August 05, 2005; Accepted: July 19, 2006. 